\title{
Biorelevant and Quality Control Dissolution Method Development and Validation of Quetiapine Fumarate Tablets
}

\author{
Muhsina Taskeen ${ }^{1}$, Mamatha Tirunagari ${ }^{1 *}$, Husna. K Qureshi² \\ 1 Department of Quality Assurance, Sultan - UI -Uloom College of Pharmacy, Road No: 3, Banjara Hills, \\ Hyderabad - 500034, Telangana State, India. \\ ${ }^{2}$ Bojjam Narasimhulu Pharmacy College for Women, Saidabad, Hyderabad - 500059, Telangana State, India.
}

\begin{abstract}
The aim of this study was to develop and validate Biorelevant and Quality control dissolution method for poorly water soluble drug Quetiapine Fumarate (QF). The Ultra Violet spectrophotometric method developed was based on the direct estimation method using $248 \mathrm{~nm}$ as $\lambda \max$. The method was validated according to International Conference on Harmonization (ICH) guidelines which include precision, specificity, accuracy and linearity. The Biorelevant dissolution medium i.e., Blank Fed State Simulated Intestinal Fluid (FeSSIF) and Quality control dissolution medium i.e., o.1N Hydro Chloric acid were selected on the basis of solubility studies. Stability studies were performed in respective dissolution mediums and the sample solutions were found to be stable for 2 days. The corresponding Biorelevant and Quality control dissolution profiles were constructed and the selected brands showed more than $85 \%$ drug release within 20 min. Thus, the proposed Biorelevant and Quality control dissolution methods can be used successfully.
\end{abstract}

Keywords: Biorelevant, Dissolution, Quetiapinefumarate, UV spectrophotometry, Validation.

\section{INTRODUCTION}

Dissolution is a required performance test for solid dosage forms, transdermal patches and suspensions. It is also only test that measures the rate of in vitro drug release as a function of time, which can reflect either reproducibility of the product manufacturing process or, in limited cases, in vivo drug release. It is an important tool in drug development and quality control ${ }^{1}$. Dissolution

*Corresponding Author: Mamatha Tirunagari

E-Mail address: tmamatha12@gmail.com 
test that can predict the in vivo performance of drug products are usually called biorelevant dissolution tests. These tests can be used to guide formulation development, to identify food effects on the dissolution and bioavailability of orally administered drugs, and to identify solubility limitations and stability issues ${ }^{2}$. Chemically quetiapine fumarate is 2-[-2(4-Dibenzo [b,f] [1.4] thiazepin-11-yl1-piperazinyl) ethoxy] ethanol fumarate salt. ${ }^{3}$ (Shown in Figure 1)

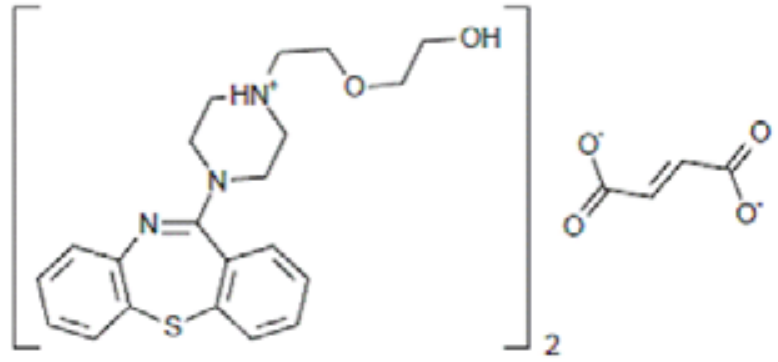

Figure 1. Chemical structure of Quetiapine fumarate.

Its molecular formula is $2\left(\mathrm{C}_{21} \mathrm{H}_{25} \mathrm{~N}_{3} \mathrm{O}_{2} \mathrm{~S}\right) \cdot \mathrm{C}_{4} \mathrm{H}_{4} \mathrm{O}_{4}$. QF appears as white crystalline solid and can be stored at room temperature ${ }^{4}$. It is an atypical antipsychotic drug, used in the treatment of psychosis associated with Parkinson's disease, chronic schizophrenia ${ }^{5}$ and bipolar disorders ${ }^{6}$. The dibenzothiazepine structure with two basic nitrogen atoms is responsible for its higher solubility under acidic conditions. At a pH above 4, the water solubility is poor; towards $\mathrm{pH} 2$, an increase in solubility is noticeable. Due to its poor solubility over the physiological pH range but because of its high permeability, quetiapine is classified as a Biopharmaceutics Classification System class II drug. ${ }^{7}$ Quetiapine's antipsychotic activity is likely due to a combination of antagonism at D2 receptors in the mesolimbic pathway and $5 \mathrm{HT} 2 \mathrm{~A}$ receptors in the frontal cortex. Antagonism at D2 receptors relieves positive symptoms while antagonism at $5 \mathrm{HT} 2 \mathrm{~A}$ receptors relieves negative symptoms of schizophrenia. ${ }^{8}$ In the present investigation an attempt was made to develop and validate a simple Biorelevant and quality control dissolution method for QF with greater precision and accuracy.

\section{MATERIALS AND METHODS}

\section{Materials}

Quetiapine fumarate pure drug was received as a gift sample for analyzing using UV spectrophotometry technique. ${ }^{9,10,11}$ Sodium Chloride, Glacial Acetic acid, Sodium taurocholate, lecithin, methylene blue, hydrochloric acid ( $\mathrm{HCl})$ and Sodium hydroxide pellets were procured from SD Fine Chem LTD (Mumbai). All reagents and solvents used were of Analytical grade. The commercial products 
of QF that is Quitipin $₫$, Qutan $₫$, Quel $₫$ were procured from local drug stores. Dissolution apparatus USP type II (USP model: TDT-o6P, Electrolabs, India) and UV Spectrophotometer (UV model 1700, Shimadzu, Japan) were used.

\section{Methods}

\section{Solubility Studies}

Solubility data was used as the basis for the selection of the best solvent for dissolution of Quetiapine fumarate tablets. It was expressed as amount of drug dissolved. For equilibrium solubility studies, excess of the drug was placed in 25 $\mathrm{ml}$ beakers containing different media: Distilled water, $0.1 \mathrm{~N} \mathrm{HCl}(\mathrm{pH}$ 1.2), $\mathrm{pH}$ 4.5 Acetate buffer, $\mathrm{pH}$ 6.5 Phosphate buffer, $\mathrm{pH} 7.4$ Phosphate buffer and Blank Fed State Simulated Intestinal Fluid (FeSSIF). The samples were gently rotated in water bath shaker at $37 \pm 0.5^{\circ} \mathrm{C}$ for $24 \mathrm{~h}$. An aliquot $(2 \mathrm{ml}$ ) was removed from each beaker after $24 \mathrm{~h}$ and filtered using $0.45 \mu \mathrm{m}$ syringe filter. $1 \mathrm{ml}$ of filtered samples were diluted with corresponding medium and analyzed by UV spectrophotometry at corresponding $\lambda_{\max }$.

\section{Stability studies}

Stability studies were performed by preparing solutions of pure drug mixture and commercial products of the drug and preserving it for 2 days. An accurately weighed quantity of pure drug and tablet powder were dissolved in sufficient quantity of $0.1 \mathrm{~N} \mathrm{HCl}$ and Blank FeSSIF to get the final stock concentration. An aliquot of these stock solutions was diluted with $0.1 \mathrm{~N} \mathrm{HCl}$ and Blank FeSSIF to get the final concentration of $10 \mu \mathrm{g} / \mathrm{ml}$. All the solutions were prepared in three replicates. The solutions were kept at $37 \pm 0.5{ }^{\circ} \mathrm{C}$ for $1 \mathrm{~h}$ under light shaking, later being left at room temperature for $48 \mathrm{~h}$. Aliquots of samples were analyzed spectrophotometrically after $1 \mathrm{~h}, 24 \mathrm{~h}$ and $48 \mathrm{~h} .{ }^{12}$

\section{Preparation of 0.1N HCl}

Conc. $\mathrm{HCl}(85 \mathrm{ml})$ was dissolved in $1 \mathrm{~L}$ of distilled water to get $0.1 \mathrm{~N} \mathrm{HCl}$ solution.

\section{Preparation of blank fed state simulated intestinal fluid (FeSSIF)}

Blank FeSSIF (pH 5.0) was prepared by dissolving $11.874 \mathrm{~g}$ of sodium chloride, $8.65 \mathrm{~g}(8.238 \mathrm{ml})$ of glacial acetic acid and $4.04 \mathrm{~g}$ of sodium hydroxide pellets in $1 \mathrm{~L}$ of distilled water.

\section{Preparation of fed state simulated intestinal fluid}

FeSSIF was prepared by dissolving $8.25 \mathrm{~g}$ of sodium taurocholate in $250 \mathrm{ml}$ of blank FeSSIF, $29.54 \mathrm{ml}$ of a solution containing $100 \mathrm{mg} / \mathrm{ml}$ lecithin in methylene chloride is added to form an emulsion, and then methylene chloride is 
eliminated under vacuum until a clear, micellar solution having no perceptible odor of methylene chloride is obtained. After cooling to room temperature, the volume is adjusted to $1 \mathrm{~L}$ with blank FeSSIF.

\section{Quality Control Dissolution Method Development and Validation}

\section{UV Method Development \& Determination of $\lambda$ max}

An accurately weighed quantity of QF was dissolved in suitable volume of $0.1 \mathrm{~N}$ $\mathrm{HCl}$ to prepare the stock solution. An aliquot from this stock solution was diluted with $0.1 \mathrm{~N} \mathrm{HCl}$ to get a final concentration of $10 \mu \mathrm{g} / \mathrm{ml}$. All solutions were prepared in three replicates. The above solutions were scanned in the range of 200$400 \mathrm{~nm}$ in $1.0 \mathrm{~cm}$ cell against $0.1 \mathrm{~N} \mathrm{HCl}$ and spectra were recorded to determine the $\lambda_{\max }$ of the drug. Figure 2 shows the UV absorption spectra of QF.

\section{Preparation of standard solutions and calibration curve}

Stock solution of QF was prepared by dissolving an accurately weighed quantity of $\mathrm{QF}$ in $0.1 \mathrm{~N} \mathrm{HCl}$. From the stock solution various concentrations i.e., 1, 2, 3, 4, 5, 6, 7, 10, 15, 20 and $25 \mu \mathrm{g} / \mathrm{ml}$ were prepared. All solutions were scanned in wavelength range of $200-400 \mathrm{~nm}$. The absorbance was plotted against the respective concentrations to obtain the calibration curve. The spectrum showing linearity of QF is given in Figure 3. The calibration data is shown in Table 3 and curve in Figure 4.

\section{Validation Parameters}

Validation of the proposed methods was carried out for its linearity \& range, accuracy, specificity and precision according to ICH guidelines..$^{13,14}$

\section{Linearity and Range}

For the determination of linearity of QF in commercial products, sample solutions of different concentrations were prepared. The stock solution of QF for all the three brands were prepared by dissolving required amount of QF in suitable volume of $0.1 \mathrm{~N} \mathrm{HCl}$. The solution was sonicated for $10 \mathrm{~min}$ and then filtered through Whatman filter paper. The solutions were further diluted to get concentrations in range of $1-25 \mu \mathrm{g} / \mathrm{ml}$.

The absorbance of the above solutions was measured at $248 \mathrm{~nm}$. A graph of absorbance $\mathrm{v} / \mathrm{s}$ concentration was plotted and correlation coefficient is calculated. The linearity data for all the three brands is presented in Table 4. The graphs were constructed as concentration v/s absorbance and depicted in Figure 5 to Figure 7.

Acceptance criteria: Correlation coefficient should be within $0.997-0.999$. 


\section{Accuracy}

The accuracy was determined by performing recovery studies at three different concentration levels i.e., 50\%, 100\%, 150\% in triplicate. The individual recovery and mean recovery values were calculated and are shown in Table 5 to 7 for all three brands.

\section{Preparation of sample solutions:}

Sample preparation of 50\%: Tablet powder equivalent to $50 \mathrm{mg}$ of $\mathrm{QF}$ and $25 \mathrm{mg}$ of QF Active Pharmaceutical Ingredient were taken in $100 \mathrm{ml}$ volumetric flask. Sufficient quantity of $0.1 \mathrm{~N} \mathrm{HCl}$ was added and sonicated to dissolve it and the volume was made up to the mark. Then the solution was filtered through Whatman filter paper and appropriate dilutions of 5,10 and $15 \mu \mathrm{g} / \mathrm{ml}$ were prepared. The absorbance of final solutions was measured at $248 \mathrm{~nm}$.

Sample preparation of $100 \%$ : Tablet powder equivalent to $50 \mathrm{mg}$ of QF and $50 \mathrm{mg}$ of QF API were taken in $100 \mathrm{ml}$ volumetric flask. Sufficient quantity of $0.1 \mathrm{~N} \mathrm{HCl}$ was added and sonicated to dissolve it and the volume was made up to the mark. Then the solution was filtered through Whatman filter paper and appropriate dilutions of 5,10 and $15 \mu \mathrm{g} / \mathrm{ml}$ were prepared. The absorbance of final solutions was measured at $248 \mathrm{~nm}$.

Sample preparation of $\mathbf{1 5 0 \%}$ : Tablet powder equivalent to $50 \mathrm{mg}$ of QF and $75 \mathrm{mg}$ of QF API were taken in $100 \mathrm{ml}$ volumetric flask. Sufficient quantity of $0.1 \mathrm{~N} \mathrm{HCl}$ was added and sonicated to dissolve it and the volume was made up to the mark. Then the solution was filtered through Whatman filter paper and appropriate dilutions of 5,10 and $15 \mu \mathrm{g} / \mathrm{ml}$ were prepared. The absorbance of final solutions was measured at $248 \mathrm{~nm}$.

The absorbance of the standard solutions of 50\%, 100\% and $150 \%$ were measured. From this individual recovery and mean recovery values were calculated.

Acceptance criteria: The \% recovery for each level should be between 98.0 to $102.0 \%$.

\section{Specificity}

The specificity of test method was established by comparing the spectra of the sample solutions of same concentration of pure drug and commercial products. The similarity in spectra was shown in Figure 8.

\section{Precision}

The precision was determined by studying repeatability and intermediate precision. The stock solution of QF for all the three brands were prepared by dissolv- 
ing an accurately weighed quantity of QF in sufficient volume of $0.1 \mathrm{~N} \mathrm{HCl}$ and sonicated for $10 \mathrm{~min}$. The sample solution was then filtered through Whatman filter paper. The solution was further diluted to get 5 and $10 \mu \mathrm{g} / \mathrm{ml}$ solutions. All dilutions were prepared in triplicate.

\section{Repeatability}

To check repeatability, the samples of concentrations $5 \mu \mathrm{g} / \mathrm{ml}$ and $10 \mu \mathrm{g} / \mathrm{ml}$ were analyzed at $248 \mathrm{~nm}$ on same day and under same experimental conditions. \% RSD was calculated and is shown in Table 8.

\section{Intermediate precision (Interday and Intraday precision)}

The interday precision was determined by analyzing the sample solutions of concentration $5 \mu \mathrm{g} / \mathrm{ml}$ and $10 \mu \mathrm{g} / \mathrm{ml}$ at $248 \mathrm{~nm}$ on different days under same experimental conditions. \% RSD was calculated is shown in Table 9.

The intraday precision was determined by analyzing the sample solutions of concentration $5 \mu \mathrm{g} / \mathrm{ml}$ and $10 \mu \mathrm{g} / \mathrm{ml}$ at $248 \mathrm{~nm}$, in two different laboratories on the same day. \% RSD was calculated is shown in Table 10.

\section{Quality Control Dissolution Method Development}

The best dissolution medium was selected on the basis of the solubility studies. Various dissolution conditions were tested for the development of a suitable dissolution method for the dissolution of QF tablets. The following dissolution conditions were selected and the analytical method used was UV spectrophotometry.

Medium: $0.1 \mathrm{~N} \mathrm{HCl}$

Volume : $900 \mathrm{ml}$

Apparatus: USP Type II (Paddle Apparatus)

RPM: 50

Temperature: $37 \pm 0.5^{\circ} \mathrm{C}$

Time interval: 10, 20, 30, $45 \mathrm{~min}$.

\section{Preparation of test solution}

A tablet was placed in each vessel of the six dissolution vessels of the tablet Dissolution Tester USP (Electrolab, India) containing $0.1 \mathrm{~N} \mathrm{HCl}$ dissolution medium after testing sink conditions. A $5 \mathrm{ml}$ aliquot of the sample was withdrawn at 10, 20, 30, $45 \mathrm{~min}$ intervals replacing $5 \mathrm{ml}$ of dissolution medium each time. The samples were filtered through Whatman filter paper. 


\section{Analysis of the dissolution samples}

The filtered dissolution samples were analyzed spectrophotometrically and \% drug release was calculated and shown in Table 11. The graph of percentage drug release versus time is shown in Figure 9.

Acceptance criteria: All the 6 tablets must show \% drug release of more than $85 \%$.

\section{Biorelevant Dissolution Method Development}

Based on solubility and stability studies the dissolution parameters includes Blank FeSSIF ( $900 \mathrm{ml}$ ) as medium in USP Type II (Paddle Apparatus) with 50 RPM maintained at temperature of $37 \pm 0.5^{\circ} \mathrm{C}$. A tablet was placed in each vessel of the six dissolution vessels after testing sink conditions. A $5 \mathrm{ml}$ aliquot of the sample was withdrawn at 10, 20, 30, $45 \mathrm{~min}$ intervals replacing $5 \mathrm{ml}$ of dissolution medium each time. The samples were filtered through Whatman filter paper. The Biorelevant dissolution samples were analyzed by UV spectrophotometry and \% drug release was calculated and shown in Table 11. The graph of \% drug release vs. time is shown in Figure 10.

Acceptance criteria: All the 6 tablets must show \% drug release of more than $85 \%$.

\section{RESULTS AND DISCUSSION}

\section{Solubility studies}

The solubility studies were performed in different media by placing excess of drug in the medium and gently shaking it for $1 \mathrm{~h}$. The samples were collected and analyzed spectrophotometrically after $24 \mathrm{~h}$. The results of solubility studies are given in Table 1. The drug is found to be soluble in $0.1 \mathrm{~N} \mathrm{HCl}$ and Blank FeSSIF. So it was selected as dissolution medium.

\begin{tabular}{|c|c|}
\hline Solvent & Solubility $(\mathbf{m g} / \mathbf{m l})$ \\
\hline Distilled water & 3.3 \\
$0.1 \mathrm{~N} \mathrm{HCl}$ & 35.6 \\
Acetate buffer pH 4.5 & 5.8 \\
Phosphate buffer pH 6.8 & 2.1 \\
Phosphate buffer pH 7.4 & 1.3 \\
Blank FeSSIF & 9.2 \\
\hline
\end{tabular}

Table 1. Solubility data of QF in different media 


\section{Stability Studies}

The stability studies were performed by analyzing sample solution of concentration $10 \mu \mathrm{g} / \mathrm{ml}$ prepared by appropriate dilutions from the stock solution of pure drug and tablet formulations of $\mathrm{QF}$ and preserving for 2 days. All samples were prepared in triplicate, the results of stability studies are given in Table 2. It was found that the sample solutions of QF are stable for $48 \mathrm{~h}$ at room temperature.

\begin{tabular}{|c|c|c|c|c|c|c|c|c|c|c|c|}
\hline \multicolumn{12}{|c|}{ Absorbance } \\
\hline \multicolumn{6}{|c|}{ Stability data of QF in $0.1 \mathrm{~N} \mathrm{HCl}$} & \multicolumn{6}{|c|}{ Stability data of QF in Blank FeSSIF } \\
\hline \multicolumn{3}{|c|}{ Pure drug } & \multicolumn{3}{|c|}{ Commercial product } & \multicolumn{3}{|c|}{ Pure drug } & \multicolumn{3}{|c|}{ Commercial product } \\
\hline $1 \mathrm{~h}$ & $24 \mathrm{~h}$ & $48 \mathrm{~h}$ & $1 \mathrm{~h}$ & $24 \mathrm{~h}$ & $48 \mathrm{~h}$ & $1 \mathrm{~h}$ & $24 \mathrm{~h}$ & $48 \mathrm{~h}$ & $1 \mathrm{~h}$ & $24 \mathrm{~h}$ & $48 \mathrm{~h}$ \\
\hline 0.474 & 0.481 & 0.487 & 0.409 & 0.411 & 0.415 & 0.355 & 0.359 & 0.348 & 0.463 & 0.467 & 0.471 \\
\hline 0.477 & 0.486 & 0.491 & 0.413 & 0.414 & 0.417 & 0.356 & 0.361 & 0.369 & 0.465 & 0.467 & 0.469 \\
\hline 0.474 & 0.482 & 0.490 & 0.410 & 0.409 & 0.412 & 0.358 & 0.363 & 0.368 & 0.461 & 0.465 & 0.473 \\
\hline
\end{tabular}

Table 2. Stability data of QF in $0.1 \mathrm{~N} \mathrm{HCl}$ and Blank FeSSIF

\section{UV Method Development and Determination of $\lambda_{\max }$}

Diluted samples of concentration $10 \mu \mathrm{g} / \mathrm{ml}$ were prepared in triplicate from standard solution of QF. The samples were scanned in the range of 200-400 nm in $1.0 \mathrm{~cm}$ cell against $0.1 \mathrm{~N} \mathrm{HCl}$. Figure 2 shows the UV absorption spectrum of QF. $\lambda_{\text {max }}$ of QF was found to be $248 \mathrm{~nm}$.

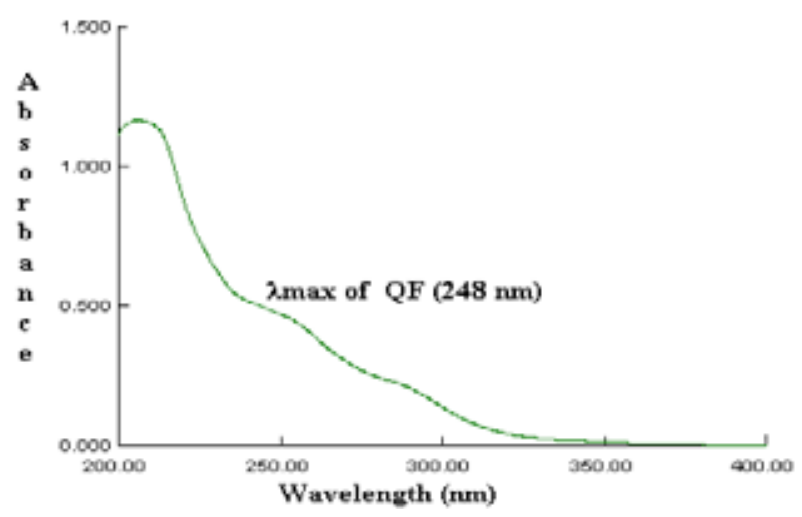

Figure 2. UV absorption spectrum of Quetiapine fumarate

The calibration curves of QF in $0.1 \mathrm{~N} \mathrm{HCl}$ were constructed and were found to be linear. Beer's law was obeyed in the concentration range of 1 to $25 \mu \mathrm{g} / \mathrm{ml}$ for QF in $0.1 \mathrm{~N} \mathrm{HCl}$. The UV spectrum for the linearity of QF is shown in Figure 3 and the calibration curve is shown in Figure 4 with data given in Table 3. 


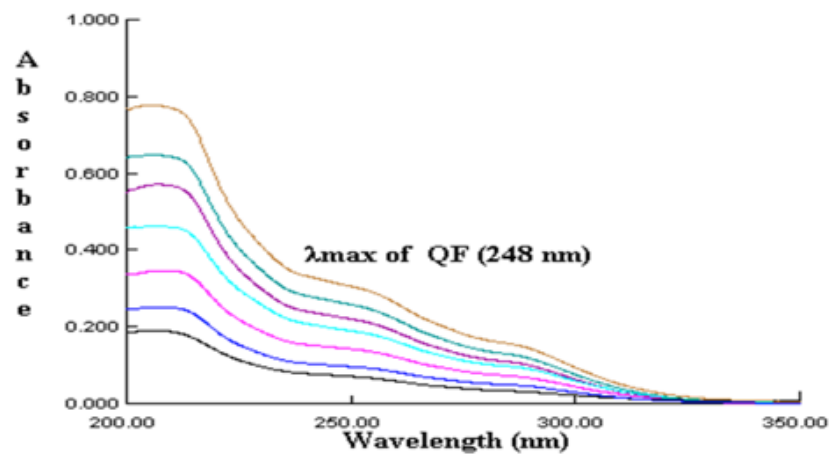

Figure 3. Linearity of $Q F$ at different concentration levels

\begin{tabular}{|c|c|c|}
\hline Serial No. & Concentration $(\boldsymbol{\mu g} / \mathrm{ml})$ & Absorbance $($ Mean \pm SD) \\
\hline 1 & 1 & $0.072 \pm 0.02$ \\
2 & 2 & $0.098 \pm 0.02$ \\
3 & 3 & $0.144 \pm 0.01$ \\
4 & 4 & $0.193 \pm 0.04$ \\
5 & 5 & $0.234 \pm 0.02$ \\
6 & 6 & $0.272 \pm 0.02$ \\
7 & 7 & $0.342 \pm 0.01$ \\
8 & 10 & $0.479 \pm 0.05$ \\
9 & 15 & $0.688 \pm 0.02$ \\
10 & 20 & $0.902 \pm 0.01$ \\
11 & 25 & $1.161 \pm 0.04$ \\
\hline
\end{tabular}

Table 3. Result of Calibration data for QF

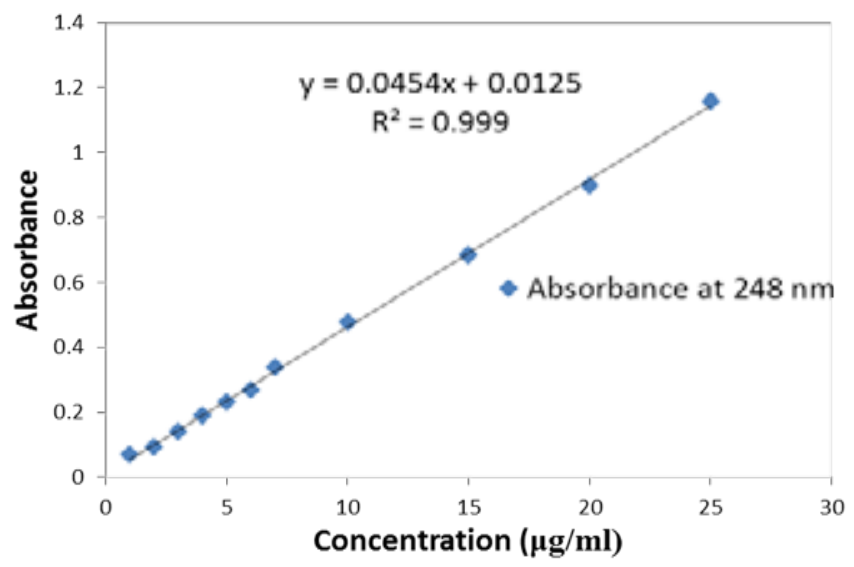

Figure 4. Calibration curve of QF Pure drug 


\section{VALIDATION}

\section{Linearity and Range}

The proposed method was found to linear in the range of $1-25 \mu \mathrm{g} / \mathrm{ml}$ for the three brands.The graphs were constructed as concentration vs. absorbance and are depicted in Figure 5, 6 \& 7. The linearity data is given in Table 4 for QF in all the three brands.

Beer's law was obeyed in concentration range of $1 \mu \mathrm{g} / \mathrm{ml}$ to $25 \mu \mathrm{g} / \mathrm{ml}$ for Quitipin $\AA$, Qutan $® \&$ Quel $®$.

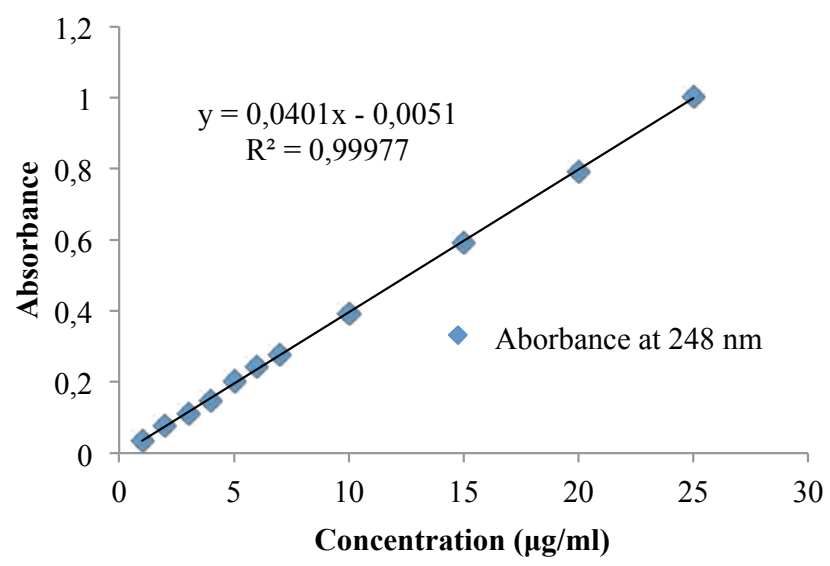

Figure 5.Linearity curve of QF in Quitipin $\circledast$

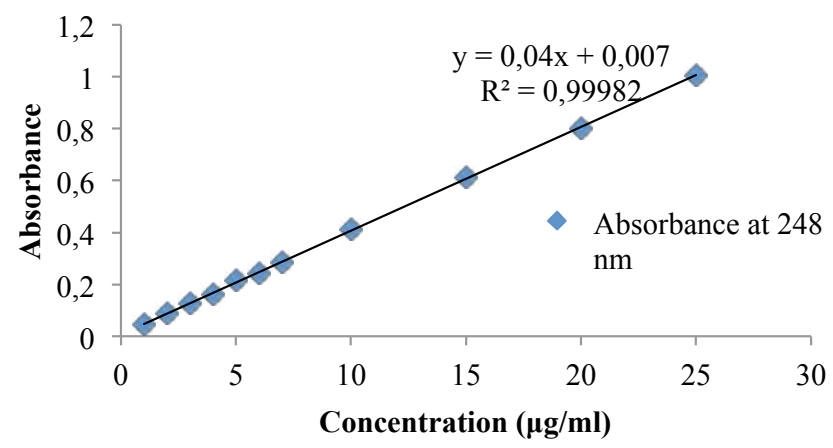

Figure 6. Linearity curve of QF in Qutan® 


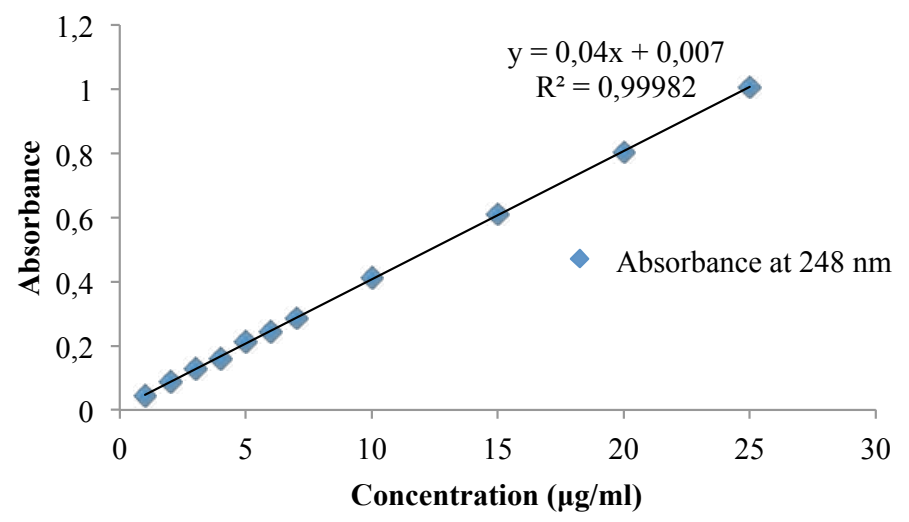

Figure 7. Linearity curve of $Q F$ in $Q u e \mid \circledast$

\begin{tabular}{|l|l|l|l|l|}
\hline \multirow{2}{*}{$\begin{array}{l}\text { Serial } \\
\text { No. }\end{array}$} & \multirow{2}{*}{$\begin{array}{l}\text { Concentration } \\
(\mu \mathrm{g} / \mathrm{ml})\end{array}$} & \multicolumn{2}{|l|}{ Absorbance (Mean \pm SD) } \\
\cline { 3 - 5 } & & Quitipin $尺$ & Qutan $\AA$ & Quel $尺$ \\
\hline 1 & 1 & $0.035 \pm 0.01$ & $0.044 \pm 0.03$ & $0.044 \pm 0.02$ \\
2 & 2 & $0.077 \pm 0.01$ & $0.087 \pm 0.02$ & $0.081 \pm 0.02$ \\
3 & 3 & $0.112 \pm 0.02$ & $0.130 \pm 0.02$ & $0.128 \pm 0.01$ \\
4 & 4 & $0.150 \pm 0.04$ & $0.160 \pm 0.04$ & $0.163 \pm 0.02$ \\
5 & 5 & $0.203 \pm 0.02$ & $0.214 \pm 0.02$ & $0.198 \pm 0.04$ \\
6 & 6 & $0.242 \pm 0.02$ & $0.244 \pm 0.01$ & $0.245 \pm 0.01$ \\
7 & 7 & $0.276 \pm 0.01$ & $0.286 \pm 0.01$ & $0.290 \pm 0.03$ \\
8 & 10 & $0.392 \pm 0.04$ & $0.412 \pm 0.02$ & $0.410 \pm 0.05$ \\
9 & 15 & $0.593 \pm 0.03$ & $0.611 \pm 0.05$ & $0.624 \pm 0.04$ \\
10 & 20 & $0.793 \pm 0.01$ & $0.804 \pm 0.03$ & $0.822 \pm 0.02$ \\
11 & 25 & $1.004 \pm 0.02$ & $1.006 \pm 0.02$ & $1.016 \pm 0.01$ \\
\hline
\end{tabular}

Table 4. Results for the linearity reading of QF in Quitipin $®$, Qutan $® \& Q u e \mid \circledast$

\section{Accuracy}

The recovery studies were performed for QF at three different concentration levels i.e., 50\%, 100\%, 150\% in triplicate. The individual recovery and mean recovery values were calculated and are shown in Table 5 to 7 for all the three brands. The \% recovery was under the acceptance criteria of $98 \%$ to $102 \%$. Thus, the method is accurate. 


\begin{tabular}{|l|l|l|l|l|}
\hline $\begin{array}{l}\text { \% Conc. at } \\
\text { specific levels }\end{array}$ & $\begin{array}{l}\text { Amount added } \\
(\mathbf{m g})\end{array}$ & $\begin{array}{l}\text { Amount } \\
\text { recovered }(\mathbf{m g})\end{array}$ & \% recovery & $\begin{array}{l}\text { Mean } \\
\text { recovery } \pm \text { SD }\end{array}$ \\
\hline & 25 & 25.22 & 100.90 & \\
$50 \%$ & 25 & 24.95 & 99.80 & $100.50 \pm 0.61$ \\
& 25 & 25.20 & 100.80 & \\
\hline & 50 & 49.80 & 99.60 & \\
$100 \%$ & 50 & 49.76 & 99.53 & $99.45 \pm 0.21$ \\
& 50 & 49.61 & 99.21 & \\
\hline $150 \%$ & 75 & 75.62 & 100.82 & \\
& 75 & 74.84 & 99.78 & $100.03 \pm 0.70$ \\
& 75 & 74.63 & 99.50 & \\
\hline
\end{tabular}

Table 5. Results of Recovery studies of Quitipin $®$

\begin{tabular}{|c|c|c|c|c|}
\hline $\begin{array}{l}\% \text { Conc. at } \\
\text { specific levels }\end{array}$ & $\begin{array}{l}\text { Amount } \\
\text { added (mg) }\end{array}$ & $\begin{array}{l}\text { Amount } \\
\text { recovered (mg) }\end{array}$ & $\%$ recovery & $\begin{array}{l}\text { Mean recovery } \\
\pm \text { SD }\end{array}$ \\
\hline $50 \%$ & $\begin{array}{l}25 \\
25 \\
25\end{array}$ & $\begin{array}{l}25.00 \\
25.03 \\
25.00\end{array}$ & $\begin{array}{l}99.99 \\
100.10 \\
99.98\end{array}$ & $100.02 \pm 0.07$ \\
\hline $100 \%$ & $\begin{array}{l}50 \\
50 \\
50\end{array}$ & $\begin{array}{l}49.43 \\
49.79 \\
49.46\end{array}$ & $\begin{array}{l}98.86 \\
99.58 \\
98.91\end{array}$ & $99.12 \pm 0.40$ \\
\hline $150 \%$ & $\begin{array}{l}75 \\
75 \\
75\end{array}$ & $\begin{array}{l}75.02 \\
75.68 \\
75.12\end{array}$ & $\begin{array}{l}100.02 \\
100.90 \\
100.16\end{array}$ & $100.36 \pm 0.47$ \\
\hline
\end{tabular}

Table 6. Results of Recovery studies of Qutan® 


\begin{tabular}{|l|l|l|l|l|}
\hline $\begin{array}{l}\text { \% Conc. at } \\
\text { specific levels }\end{array}$ & $\begin{array}{l}\text { Amount added } \\
(\mathbf{m g})\end{array}$ & $\begin{array}{l}\text { Amount } \\
\text { recovered }(\mathbf{m g})\end{array}$ & \% recovery & $\begin{array}{l}\text { Mean } \\
\text { recovery } \pm \text { SD }\end{array}$ \\
\hline $50 \%$ & 25 & 25.03 & 100.12 & 100.20 \\
& 25 & 25.05 & 99.99 & $100.10 \pm 0.11$ \\
& 25 & 25.00 & 101.10 & \\
\hline $100 \%$ & 50 & 50.55 & 100.99 & $101.07 \pm 0.07$ \\
& 50 & 50.50 & 101.12 & \\
\hline $150 \%$ & 50 & 50.56 & 98.98 & \\
& 75 & 74.24 & 99.81 & $99.56 \pm 0.50$ \\
& 75 & 74.86 & 99.89 & \\
\hline
\end{tabular}

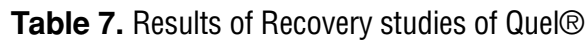

\section{Specificity}

The method was confirmed to be specific by analyzing samples of pure drug and commercial products. It was observed that there was no interference of the excipients. (Represented in Figure 8)

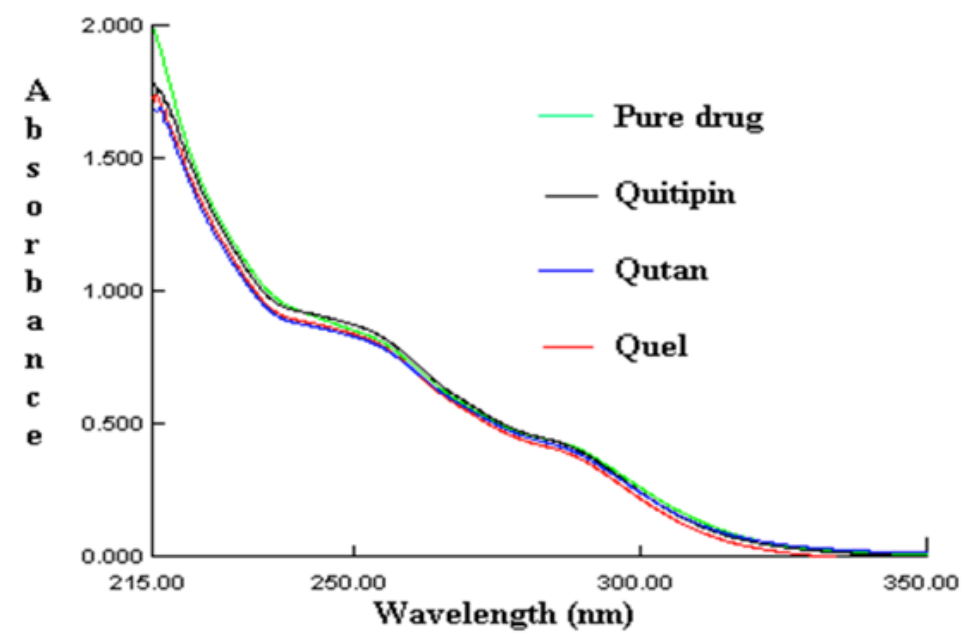

Figure 8. Spectra of pure drug and commercial products 


\section{Precision}

The precision was determined by Repeatability (Table 8), Inter day (Table 9) and Intraday precision (Table 10) and the \% RSD was found to be less than $2 \%$ for all the three brands.

The low \% RSD values indicate that the method is precise.

\begin{tabular}{|l|l|l|l|}
\hline Brand & $\begin{array}{l}\text { Concentration } \\
\text { prepared }(\boldsymbol{\mu g} / \mathrm{ml})\end{array}$ & Concentration* $(\boldsymbol{\mu g} / \mathrm{ml})$ & $\%$ RSD \\
\hline Quitipin® & 5 & $\begin{array}{l}5.13 \pm 0.04 \\
10.05 \pm 0.02\end{array}$ & $\begin{array}{l}0.74 \\
0.25\end{array}$ \\
\hline Qutan $尺$ & 5 & $4.78 \pm 0.02$ & 0.52 \\
& 10 & $10.14 \pm 0.07$ & 0.71 \\
\hline Quel® & 5 & $4.64 \pm 0.04$ & 0.80 \\
& 10 & $9.86 \pm 0.09$ & 0.87 \\
\hline
\end{tabular}

Table 8. Results for Repeatability

\begin{tabular}{|c|c|c|c|c|c|}
\hline \multirow[t]{2}{*}{ Brand } & \multirow{2}{*}{$\begin{array}{l}\text { Concentration } \\
\text { prepared }(\mu \mathrm{g} / \mathrm{ml})\end{array}$} & \multicolumn{2}{|c|}{ Concentration* $(\mu \mathrm{g} / \mathrm{ml})$} & \multicolumn{2}{|c|}{$\%$ RSD } \\
\hline & & Day 1 & Day 2 & Day 1 & Day 2 \\
\hline \multirow[t]{2}{*}{ Quitipin $尺$} & 5 & $5.13 \pm 0.04$ & $4.77 \pm 0.02$ & 0.74 & 0.52 \\
\hline & 10 & $10.05 \pm 0.02$ & $9.55 \pm 0.07$ & 0.25 & 0.69 \\
\hline \multirow[t]{2}{*}{ Qutan $®$} & 5 & $4.78 \pm 0.02$ & $5.11 \pm 0.03$ & 0.52 & 0.57 \\
\hline & 10 & $10.14 \pm 0.07$ & $10.12 \pm 0.05$ & 0.71 & 0.51 \\
\hline \multirow[t]{2}{*}{ Quel $\circledast$} & 5 & $4.64 \pm 0.04$ & $4.57 \pm 0.04$ & 0.80 & 0.82 \\
\hline & 10 & $9.86 \pm 0.09$ & $9.65 \pm 0.09$ & 0.87 & 0.96 \\
\hline
\end{tabular}

Table 9. Results for Intermediate Precision (Interday) 


\begin{tabular}{|c|c|c|c|c|c|}
\hline \multirow[t]{2}{*}{ Brand } & \multirow{2}{*}{$\begin{array}{l}\text { Concentration } \\
\text { prepared }(\mu \mathrm{g} / \mathrm{ml})\end{array}$} & \multicolumn{2}{|c|}{ Concentration* $(\mu \mathrm{g} / \mathrm{ml})$} & \multicolumn{2}{|l|}{$\%$ RSD } \\
\hline & & Lab 1 & Lab 2 & Lab 1 & Lab 2 \\
\hline \multirow[t]{2}{*}{ Quitipin $®$} & 5 & $5.13 \pm 0.04$ & $5.02 \pm 0.04$ & 0.74 & 0.76 \\
\hline & 10 & $10.05 \pm 0.02$ & $10.00 \pm 0.09$ & 0.25 & 0.86 \\
\hline \multirow[t]{2}{*}{ Qutan® } & 5 & 4.780 .02 & 4.830 .02 & 0.52 & 0.52 \\
\hline & 10 & 10.140 .07 & 9.900 .05 & 0.71 & 0.51 \\
\hline \multirow[t]{2}{*}{ Quel $\mathbb{R}$} & 5 & $4.64 \pm 0.04$ & $4.85 \pm 0.02$ & 0.80 & 0.50 \\
\hline & 10 & $9.86 \pm 0.09$ & $9.95 \pm 0.05$ & 0.87 & 0.51 \\
\hline
\end{tabular}

Table 10. Results for Intermediate Precision (Intraday)

\section{Quality Control and Biorelevant Dissolution Method Development}

The filtered Quality control dissolution samples \& Biorelevant dissolution samples were analyzed spectrophotometrically and \% drug release was calculated and shown in Table 11. The graph of \% drug release versus time is shown in Figure 9 \& Figure 10 respectively.By employing the optimized conditions for dissolution, \% drug release of more than $85 \%$ was achieved within 20 min for all the three brands.

\begin{tabular}{|c|c|c|c|c|c|c|}
\hline \multirow{3}{*}{$\begin{array}{l}\text { Time } \\
\text { (mins) }\end{array}$} & \multicolumn{6}{|c|}{$\%$ Drug release* $($ Mean \pm SD) } \\
\hline & \multicolumn{3}{|c|}{$\begin{array}{l}\text { Dissolution of QF in } \\
\text { commercial products }\end{array}$} & \multicolumn{3}{|c|}{$\begin{array}{l}\text { BioRelevant Dissolution of QF in } \\
\text { commercial products }\end{array}$} \\
\hline & Qutipin® & Qutan® & Quel@ & Qutipin® & Qutan® & Quel® \\
\hline 10 & $78.66 \pm 2.1$ & $77.58 \pm 2.5$ & $75.96 \pm 4.1$ & $75.4 \pm 2.6$ & $72.72 \pm 3.1$ & $77.94 \pm 2.7$ \\
\hline 20 & $93.42 \pm 3.2$ & $92.7 \pm 3.3$ & $90.18 \pm 3.9$ & $86.8 \pm 2.1$ & $87.48 \pm 3.4$ & $89.28 \pm 3.2$ \\
\hline 30 & $97.56 \pm 2.5$ & $95.04 \pm 3.8$ & $94.68 \pm 4.6$ & $94.3 \pm 3.7$ & $94.14 \pm 4.0$ & $96.48 \pm 3.7$ \\
\hline 45 & $101.2 \pm 3.2$ & $100.8 \pm 4.1$ & $100.5 \pm 3.5$ & $98.92 \pm 3.5$ & $98.28 \pm 3.6$ & $100.8 \pm 2.5$ \\
\hline
\end{tabular}

*Average of 6 determinations

Table 11. Results for Dissolution and Biorelevant Dissolution of commercial products 


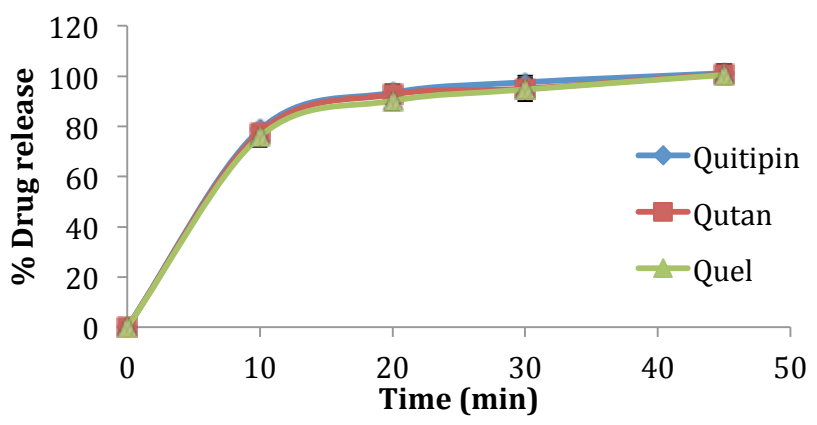

Figure 9.Dissolution profile of QF in commercial products.

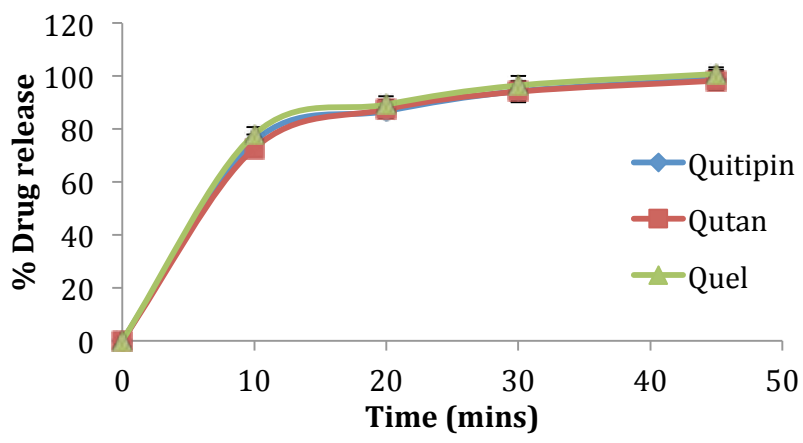

Figure 10. Biorelevant Dissolution profile of QF in commercial products.

\section{CONCLUSION}

Biorelevant and quality control dissolution methods were developed and validated. The best dissolution medium selected on the basis of solubility studies for quality control dissolution was $0.1 \mathrm{~N} \mathrm{HCl}$ and the medium for biorelevant dissolution was Blank FeSSIF. The stability studies were performed and the sample solutions were found to be stable for 2 days. The analytical method developed was UV spectrophotometric method involving direct estimation method for $\mathrm{QF}$. The $\lambda$ max of QF was found to be $248 \mathrm{~nm}$. The method was validated for various parameters like linearity, precision, accuracy and specificity. All the parameters were found to be under the acceptance criteria. The quality control dissolution profile and Biorelevant dissolution profile was obtained by using 900 $\mathrm{ml}$ of dissolution medium containing $0.1 \mathrm{~N} \mathrm{HCl}$ and Blank FeSSIF respectively maintained at $37^{\circ} \pm 0.5^{\circ} \mathrm{C}$ with paddle apparatus at $50 \mathrm{rpm}$ for $45 \mathrm{~min}$. More than $85 \%$ of the drug was released within 20 min. Thus, the methods developed were precise, accurate and reproducible and can be employed as quality control and biorelevant method. 


\section{ACKNOWLEDGEMENT:}

The authors are thankful to the management of Sultan-ul-Uloom College of Pharmacy for providing necessary facilities to carry out this work.

Declaration of Interest: We do not have any conflict of interest and solely are responsible for content and writing of the paper.

\section{REFERENCES}

1. Quingxi, W.; Decheng, M.; John, P. Analytical method selection for drug product dissolution testing. Dissolution Technol. 2006, 8(1), 6-13.

2. Shah. V.P. Dissolution a quality control test vs a bioequivalence test. Dissolution Technol. 2006, 11(1), 1-2.

3. Bhanudas, S. K.; Sanjay, P. Preformulation and formulation studies of novel pH independent controlled release drug delivery system of quetiapine fumarate. J. Pharm. Res. 2009,2, 110-119.

4. Valarmathi, R.; Dhivya Dharshini,C. S.; Senthamarai, R.; Farisha Banu, S. Analytical method development of Quetiapine Fumarate in bulk and its Tablet Formulation by simple UV Spectrophotometry. Int. J. Drug Dev. Res. 2013, 5(1), 366-372.

5. Seeman, P.; Atypical antipsychotics: mechanism of action. Can $J$ Psychiatry. 2002, 47(1), 27-38.

6. Kalyankar, P.; Panade, P.; Lahoti, S. Formulation design and optimization of orodispersible tablets of quetiapine fumarate by sublimation method. Indian J Pharm Sci. 2015, 77(3), 267-273.

7. Grzegorz Garbacz; Anna Kandzi; Mirko Koziolek; Jarosław Mazgalski; Werner Weitschies. Release characteristics of quetiapine fumarate extended release tablets under biorelevant stress test conditions. AAPS Pharm. Sci. Tech. 2014,15(1), 230-236.

8. Martindale. The complete drug reference, $34^{\text {th }}$ ed.; Pharmaceutical Press, London, 2005; pp 76.

9. Srihari, G.; Chakravarthi, I. E. Simple spectrophotometric method for determination of Quetiapine fumarate in tablets. Int. J. Chem. Sci. 2011, 9(2), 949-952.

10. Sudarshan Reddy, P.; Ashok Reddy, S.; Karthikvarma, K.; Narasimha Rao, D.; Panjagala Satyanarayana; Naga Raju, T. M. Method development and validation of Quetiapine fumarate bulk and in tablet dosage form by using UV-Spectrophotometry. Int. J. Pharm \& Ind. Res. 2o11, 1(3), 195-199.

11. Prasanth, V. G.;Susamma Cicy Eapen; Sheeja Velayudhan Kutty; Jyothi T. S. Development and validation of Quetiapine fumarate in pure and pharmaceutical formulation by UV Spectrophotometric method. Der Pharmacia Sinica. 2o11, 2(6), 52-58.

12. Rochelle, C.R.; Carolina, L.D.; Lisiane, B.; Ana, M. B.; Pedro, E.H. Development and validation of discriminating method of dissolution for Fosamprenavir tablets based on in vivo data. $J$. Pharm. Biomed. 2011, 54(1), 439-444.

13. International Conference on Harmonization, Q2 (R1); Draft guidance on Validation of analytical procedures, Federal register; 1997, 62(96), pp 27463-27467.

14. Jennifer, D., Johannes, K. Pharmaceutical dissolution testing, Taylor and Francis, Indian ed., pp. 352-353.

(Received o4 September 2016; accepted 19 October 2016) 